\title{
RESEARCH OF IMPULSE PROPERTIES OF INDUM PHOSPHIDE
}

\author{
Saurova T., Kuzmenko D. \\ National technical university of Ukraine "Igor Sikorsky Kyiv Polytechnic Institute" \\ Kyiv, Ukraine \\ E-mail: saurowa@phbme.kpi.ua; denis44401@gmail.com
}

\begin{abstract}
A theoretical research of the indium phosphide impulse properties has been carried out. The effect of the "overshoot" of the charge carriers drift velocity is analyzed. The influence of the electric field impulse parameters on the time and space distribution of the drift velocity was analyzed numerically. It is shown that the effect of the high electric field rectangular impulse on indium phosphide causes a short-term "overshoot" of the drift velocity. If the electric field is becoming stronger, the peak value of the drift velocity is getting higher but the duration of the "overshoot" is reducing. It is showing that the impulse duration does not affect the magnitude of the "overshoot" and the rate of relaxation processes. With increasing of the rectangular Impulse front duration peak values of high field "overshoot" are reducing. The impulse properties of indium phosphide and gallium arsenide were compared.
\end{abstract}

Keywords: indium phosphide, impulse properties, the effect of the drift velocity "overshoot".

\section{INTRODUCTION}

The improvement of semiconductor electronic components and devices requires a theoretical research of the properties and technological development of new materials. One of the well-proven materials among of binary compounds is indium phosphide.

The purpose of this article is to research the influence of ballistic effects on drift processes: the time and space distribution of the drift velocity under the impulse effect of the electric field. The results of numerical modelling give the new information about the dynamic properties of InP in a high electric field.

\section{MAIN PART}

A numerical experiment was carried out using a technique based on the relaxation equations for conservation of momentum, energy, and concentration [1]. The calculations were performed using the initial values of the material parameters described in [2], [3]. The corresponding field-velocity relation of indium phosphide is in good agreement with the experimental data [3-9] (fig. 1).

The presented field-velocity curve corresponds to the static electric field mode. It is known that the phenomenon of "overshoot" of drift velocity is manifested if the impulse electric field is applied. It leads to a significant, several times, increase of the drift velocity in comparison with its steady-state value. Fig. 2 shows changes (temporal and dimensional) of the drift velocity under the abrupt increase of the electric field strength, as well as the dynamics of the population of the valleys, electron temperature, momentum and energy relaxation times. The calculation was done for the amplitudes of a rectangular impulse corresponding to the characteristic values of the field-velocity characteristic presented: $2,7 \mathrm{kV} / \mathrm{cm}$ and $70 \mathrm{kV} / \mathrm{cm}$ - "low" and "high" electric field with the same value of $v_{d r}, 10$ $\mathrm{kV} / \mathrm{cm}$ - "critical" for InP electric field, $100 \mathrm{kV} / \mathrm{cm}$ saturation mode $v_{d r}$. The pulse duration 3 ps corresponds in the order of magnitude to the largest interval (3...5) $\tau_{E}$.

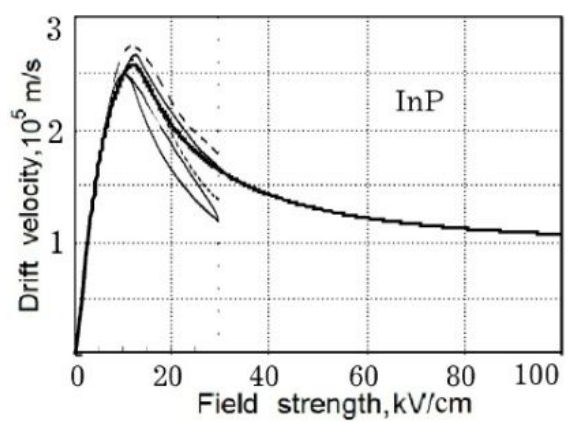

Fig. 1. Field-velocity curve of indium phosphide: modelling results (solid) and experimental (dashed and dotted), taken from [3]

A ballistic movement, without scattering processes, of an electron in the electric field $E$ with the acceleration $e E / m^{*}$ corresponds to the ascending section of the curves $v_{d r}(t)$ (fig. 2.a). At the same time, with the increase of the drift velocity, the electron gas heats up (fig. 2.b), creating conditions for the process of redistribution of electrons between the valleys (figure 2.c). After the time of the order of $\tau_{p}$, the timedependence $v_{d r}(t)$ decreases, which is related to the increase of the population of the upper valleys (fig. 2.c) and relaxation processes (fig. $2 d, 2 . e$ ). The transient process of the drift velocity is completed by the attainment of a steady state, to which the parameters of the drift motion in a static electric field correspond. 


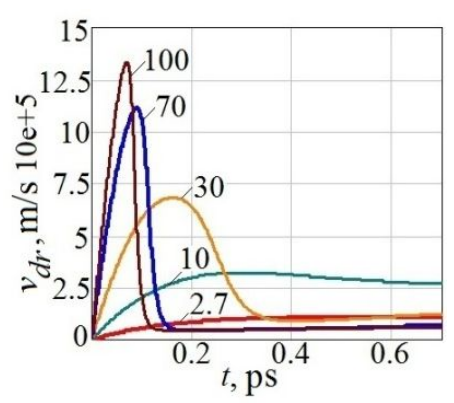

$a$

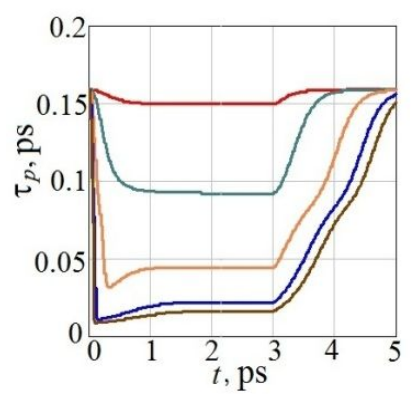

$d$

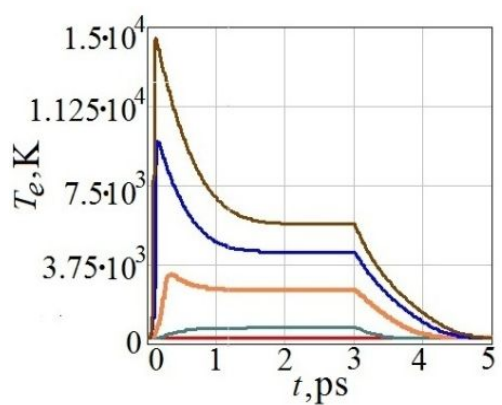

$b$

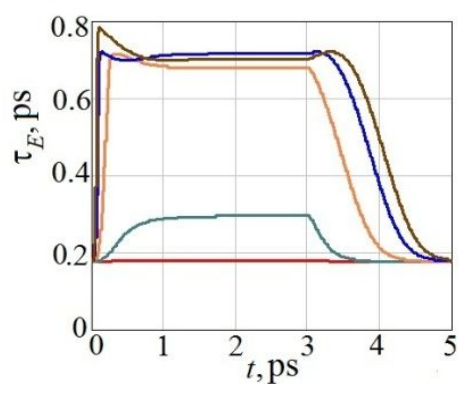

$e$

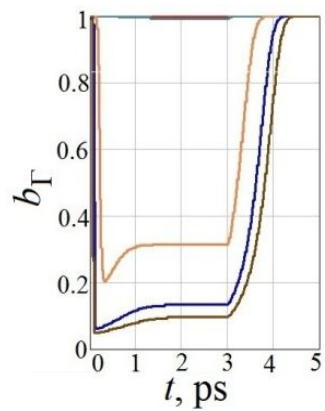

$c$

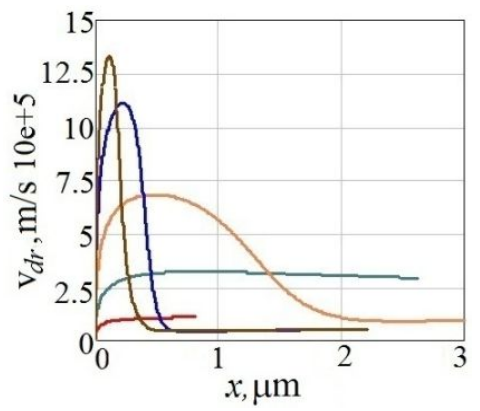

F

Fig. 2. Effect of the rectangular impulse on: $(a)$ drift velocity $v_{d r}$; $(b)$ electron temperature $T_{e} ;(c)$ population of the $\Gamma$-valley $b_{\Gamma} ;(d)$ momentum relaxation time $\tau_{p},(e)$ energy relaxation time $\tau_{E} ;(f)$ drift velocity space distribution

The abrupt increase of the electric field leads to a short-time excess ("overshoot") of the drift velocity against the steady-state value. As the amplitude of the high-field pulse increases, the peak values $v_{d r}(t)$ increase (by 4 ... 12 times). The electric fields at which the heating of the electron gas leads to a significant (more than half) decrease in the population of the lowest valley (for indium phosphide, the $\Gamma$-valley) can be attributed to high ones. In high fields $-30 \mathrm{kV} / \mathrm{cm}, 70$ $\mathrm{kV} / \mathrm{cm}, 100 \mathrm{kV} / \mathrm{cm}$ (fig. 2.c), the effect of the negative "undershoot" of the drift velocity is also observed on the curves $v_{d r}(t)$, a decrease below the stationary value. This effect is caused by the difference in the relaxation times of electrons moving in the opposite direction along the field. In the well-known literature is shows that with the undershoot effect, the drift velocity can be negative, and for the research the Monte Carlo method is only required [10].

The space distribution of the drift velocity $v_{d r}(x)$ is calculated from the time dependence of $v_{d r}(t)$

$$
x(t)=\int_{0}^{t} v(t) d t .
$$

It is found that the length of the "ballistic distance" with increasing of the electric field strength is reduced (fig. 2.f).

Fig. 3 shows the dynamics of the drift velocity under the effect of the electric field impulse (with the amplitude of $70 \mathrm{kV} / \mathrm{cm}$ ) of different duration.
In this numerical experiment the peak value $\mathrm{v}_{d r}$ and the rate of relaxation processes are independent of the pulse duration.

A theoretical research of the response on the trapezoidal pulse of the high electric field was carried out. Duration of the front and rear edges of the electic field pulse is chosen to be the same. Fig. 4 shows the results of modelling of the response to a high-field pulse with different front durations (at the electric field strength of $100 \mathrm{kV} / \mathrm{cm}$ ).

As we can see from the graphs, an increase of the pulse front edge of the high electric field leads to a significant decrease of the electron temperature and a less increase of the impulse relaxation time. The first factor leads to a later devastation of the $\Gamma$-valley. A more fluently increasing of electric field reduces the magnitude of the "overshoot" of the velocity of the ballistic motion of the carriers. The resultant effect of these factors is a decrease of the "overshoot" $v_{d r}$ and its delay.

The results of calculations showed that an increase in the duration of the pulse front of a high electric field:

- reduces the peak drift velocity;

- increases the length of the "ballistic distance";

- weakens the undershoot effect.

The conducted researches are actual for development of nano- and picosecond equipment. 


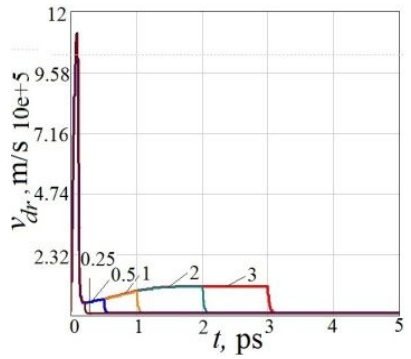

$a$

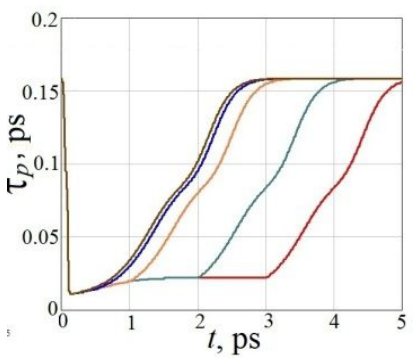

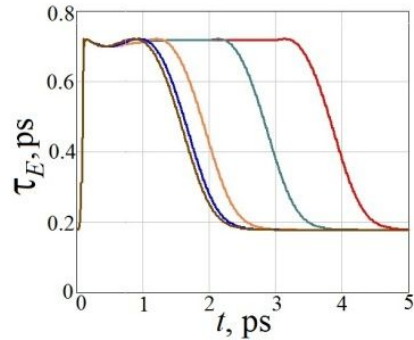

Fig. 3. Dynamics of the effect of a rectangular high field impulse of the different duration on: $(a)$ drift velocity $v_{d r}$; relaxation times of the pulse $\tau_{p}(b)$ and the energy $\tau_{E}(c)$

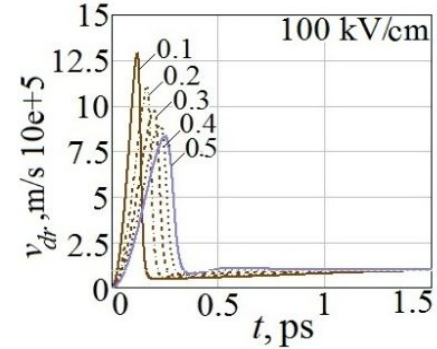

$a$

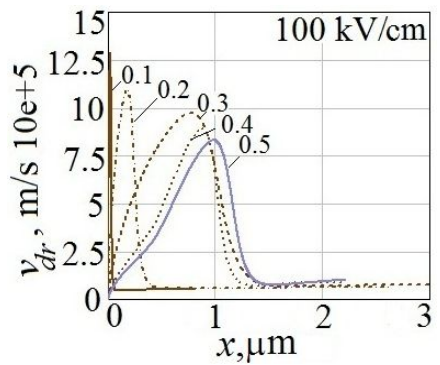

$b$

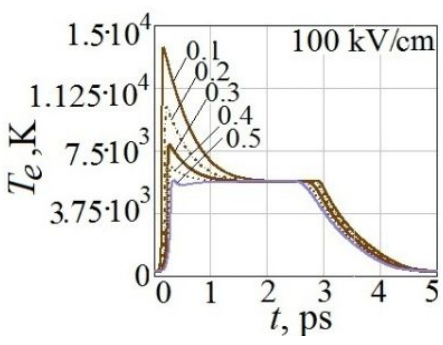

C

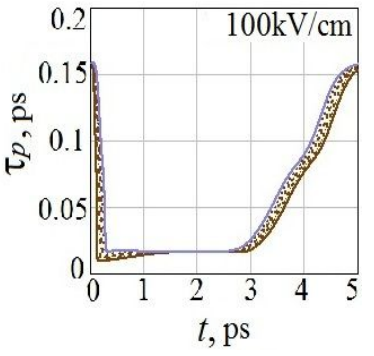

$d$

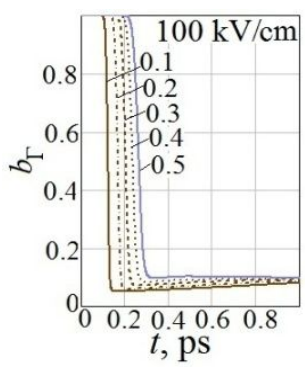

$e$

Fig. 4. Dynamics of the effect of a rectangular high field pulse with different duration of the fronts: $(a, b)$ drift velocity $v_{d r}(t), v_{d r}(x) ;(c)$ electron temperature $T_{e} ;(d)$ momentum relaxation time $\tau_{p} ;(e)$ population of the $\Gamma$-valley $b_{\Gamma}$. Amplitude of the electric field pulse is $100 \mathrm{kV} / \mathrm{cm}$. The front durations varied from $0.1 \mathrm{ps}$ to $0.5 \mathrm{ps}$.

\section{Conclusions}

The effect of a rectangular impulse of a high electric field on InP leads to a short "overshoot" of the drift velocity. With the increasing of the electric field, the peak values of the "overshoot" are increasing, and the duration of the "overshoot" is reducing, corresponding in order of magnitude to the values of $\tau_{p}(E)$. In the numerical experiment, the maximum drift velocity $\left(13,3 \cdot 10^{5} \mathrm{~m} / \mathrm{s}\right)$ was obtained under the amplitude (electric field strength) of the pulse of $100 \mathrm{kV} / \mathrm{cm}$.

The pulse duration does not affect the magnitude of the "overshoot" and the rate of relaxation processes. As the duration of the rectangular pulse front of the high field is increasing, the peak values of the "overshoot" are decreasing.

The InP has a GaAs-like band structure, which leads to a similar mechanism for the origin of the drift velocity "overshoot". Comparing the impulse proper- ties of InP and $\mathrm{GaAs}$, the most used $\mathrm{A}_{3} \mathrm{~B}_{5}$ compound semiconductors in electronics, we note:

- $\quad$ in the impulse mode of electric fields up to $\sim 30$ $\mathrm{kV} / \mathrm{cm}$, the largest values of $v_{d r}$ are for GaAs [3];

- in the impulse mode of high electric fields (above $\sim 40 \mathrm{kV} / \mathrm{cm}$ ), the largest values of $v_{d r}$ correspond to InP.

The effect of the "overshoot" makes it possible to significantly increase the average carrier velocity at distances of the order of $0.1 \mu \mathrm{m}$, that is relevant for submicron devices.

The results of numerical modelling give the new information about the dynamic properties of InP in a high electric field. The conducted researches are actual for development of nano- and picosecond equipment. 


\section{References}

[1] V. A. Moskaliuk, Physics of electron processes. Dynamic processes, Kyiv: Polytechnika, 2004, p. 180.

Москалюк В.А. Физика электронных процессов. Динамические процессы. - К.: политехника, 2004. - $180 \mathrm{c}$.

[2] Ioffe Physico-Technical Institute, "New Semiconductor Materials. Characteristics and Properties." [Online]. Available: http://www.ioffe.ru/SVA/NSM/Semicond/InP.

[3] V. A. Moskaliuk, V. I. Timofeyev and A. V. Fedyay, High-Speed Electronics Devices, Kyiv: Polytechnika, 2012, p. 479.

[4] T. Gonzalez Sanchez, J. E. Velazquez Perez, P. M. Gutierrez Conde and D. Pardo, Semiconductor Science and Technology, vol. 7, no. 1, pp. 31-36, 1992.
[5] T. J. Maloney and J. Prey, J. Appl. Phys., vol. 48, no. 2, pp. 781-787, 1977.

[6] T. H. Windhorn, L. W. Cook, M. A. Haase and G. E. Stillman, Appl.Phys. Lett., vol. 42, no. 8, pp. 725-727, 1983.

[7] W. Fawcett and G. Hill, Electron. Lett, vol. 11, no. 4, pp. 80-81, 1975.

[8] V. A. Moskaliuk and K. K. Bol, "Proc. IEEE XXXIV International Scientific Conference ELECTRONICS AND NANOTECHNOLOGY," Ballistic transport in threenitrids, Kyiv, Ukraine, 2014.

[9] V. A. Moskaliuk and K. K. Bol, Electronics and Communications, vol. 19, no. 5(82), pp. 26-31, 2014.

[10] M. Shur, Modern Devices Based on Gallium Arsenide, Moscow: Mir, 1991, p. 632.

\section{УДК 621.382 .3}

\section{Т. А. Саурова, Д. П. Кузьменко}

Національний технічний університет Украйни «Київський політехнічний інститут імені Ігоря Сікорського», Київ, Україна

\section{ДОСЛІДЖЕННЯ ІМПУЛЬСНИХ ВЛАСТИВОСТЕЙ ФОСФІДУ ІНДІЯ}

Проведено теоретичне дослідження імпульсних властивостей фосфіду індію. Дан аналіз ефекту «сплеску» дрейфової швидкості носіїв заряду. Проведено чисельний експеримент впливу параметрів імпульсу електричного поля на тимчасовий та просторовий розподіл дрейфової швидкості. Показано, що дія прямокутного імпульсу сильного електричного поля в $\mathrm{InP}$ призводить до короткочасного «сплеску» швидкості дрейфу. Отримано, що з посиленням поля пікові значення швидкості зростають, а тривалості «сплеску» скорочуються. Показано, що тривалість імпульсу не впливає на величину «сплеску» і швидкість релаксаційних процесів. Зі збільшенням тривалості фронту прямокутного імпульсу сильного поля пікові значення «сплеску» зменшуються. Проведено порівняння імпульсних властивостей фосфіду індію та арсеніду галію.

Ключові слова: фосфід індію, імпульсні властивості, ефект «сплеску» дрейфової швидкості.

\section{Т. А. Саурова, Д. П. Кузьменко}

Национальный технический университет Украинь «Киевский политехнический институт имени Игоря Сикорского», г. Киев, Украина ИССЛЕДОВАНИЕ ИМПУЛЬСНЫХ СВОЙСТВ ФОСФИДА ИНДИЯ

Проведено теоретическое исследование импульсных свойств фосфида индия. Дан анализ эффекта «всплеска» дрейфовой скорости носителей заряда. Проведен численный эксперимент влияния параметров импульса электрического поля на временное и пространственное распределение дрейфовой скорости. Показано, что действие прямоугольного импульса сильного электрического поля в InP приводит к кратковременному «всплеску» скорости дрейфа. Получено, что с усилением поля пиковые значения скорости возрастают, а длительности «всплеска» сокращаются. Показано, что длительность импульса не влияет на величину «всплеска» и скорость релаксационных процессов. С увеличением длительности фронта прямоугольного импульса сильного поля пиковые значения «всплеска» уменьшаются. Проведено сравнение импульсных свойств фосфида индия и арсенида галлия.

Ключевые слова: фосфид индия, импульсные свойства, эффект «всплеска» дрейфовой скорости.

Надійшла до редакиії 04 листопада 2017 року

Рецензовано

(C) Saurova T., Kuzmenko D., 2017

18 листопада 2017 року 